\title{
Palaeoecological inferences about dinosaur gregarious behaviour based on the study of tracksites from La Rioja area in the Cameros Basin (Lower Cretaceous, Spain)
}

\author{
E. García-Ortiz ${ }^{1 *}$, F. Pérez-Lorente ${ }^{2}$ \\ ${ }^{1}$ Universidad de León, Área de Paleontología, Dpto. Geografía y Geología, Facultad de Filosofía y Letras, Campus de \\ Vegazana s/n, 24071 León, Spain. \\ ${ }^{2}$ Edificio C. T. U., Universidad de La Rioja. Madre de Dios, 51, 26006 Logroño (La Rioja), Spain. \\ e-mail addresses: cloessense@hotmail.com (E.G.-O., *corresponding author); felix.perez@unirioja.es (F.P.-L.)
}

Received: 25 September 2013 / Accepted: 4 December 2013 / Available online: 25 February 2014

\begin{abstract}
In La Rioja the widespread ichnological record of dinosaurs ranges from the Berriasian to the Aptian age (Early Cretaceous). There, due to the high palaeodiversity, several evidences of gregarious behaviour can be observed in different types of footprints (sauropods, theropods and ornithopods). Moreover, due to the huge dimensions of some sites, different types of dinosaur tracks representing gregarious behaviour can be found very close in space and time. All these evidences have been compiled and analysed, obtaining an overview of this type of behaviour in relation to the type of trackmaker. Twenty-eight evidences of gregariousness have been found, of which nine are of sauropod footprints, twelve of theropod, seven of ornithopod, and one of unknown bipedal dinosaurs. These data have been further divided into accumulations and sets of parallel trackways. In sauropod footprints the main evidence is represented by the accumulations of tracks made by herds of individuals of the same size. In ornithopod footprints there are accumulations and parallel trackways of large size individuals and even family groups. In theropod footprints, sets of parallel trackways of few individuals of the same size (from small to medium) are the most common evidence and there are no data about gregariousness in large theropod footprints. Thus, data were obtained on different sizes of herds, size of individuals and structure of the groups depending on different ichnotypes, providing information about important palaeoecological aspects of their trackmakers, such as population structure.
\end{abstract}

Keywords: dinosaurs, footprints, gregarious behaviour, Cretaceous, La Rioja, Spain

Resumen

En La Rioja existe un abundante registro icnológico de dinosaurios en materiales de edades Berriasiense-Aptiense (Cretácico Inferior). En ellos se pueden observar diferentes muestras de comportamiento gregario en distintos tipos de huellas (saurópodas, terópodas y ornitópodas). Incluso debido al gran tamaño de algunos yacimientos, se pueden encontrar muestras de comportamiento gregario de distintos tipos de dinosaurios muy próximas en el espacio y en el tiempo. Se han recopilado todas estas evidencias y se han analizado para obtener así una visión global de este tipo de comportamiento en funcion de los dinosaurios que las produjeron. Se ha obtenido un total de veintiocho evidencias de gregarismo, de las cuales nueve son de icnitas saurópodas, doce de terópodas, siete de ornitópodas y una de dinosaurios bípedos indeterminados. Todas estas evidencias se han dividido en acumulaciones y conjuntos de rastros paralelos. En icnitas saurópodas se observan fundamentalmente acumulaciones de huellas atribuidas a manadas constituidas todas por individuos de talla media. En cuanto a icnitas ornitópodas, hay acumulaciones y conjuntos de rastros paralelos de individuos de gran tamaño así como grupos familiares de pocos individuos. En icnitas terópodas se observan más evidencias de conjuntos de rastros paralelos con individuos generalmente de talla semejante (pequeña a mediana). Sin embargo, no se han encontrado evidencias de gregarismo en icnitas terópodas de gran tamaño. De esta manera, se han obtenido datos sobre diferentes patrones de tamaños de manadas, talla de los individuos y estructura de las agrupaciones en función de los diferentes icnotipos, proporcionando así información sobre importantes aspectos paleoecológicos de los animales que las produjeron así como de sus estructuras poblacionales. 


\section{Introduction}

Many aspects of dinosaurs behaviour have been studied over the last few years and are still of interest to the scientific community for their palaeobiological and palaeoenvironmental meaning (Lockley, 1986). One of the most controversial aspects is the group behaviour or gregariousness (Ostrom, 1972; Soler et al., 2001; Lucas, 2007), which is often used incorrectly as synonym of social behaviour (García-Ortiz and Pérez-Lorente, 2012a).

According to Ostrom (1972, p. 287), the term "gregarious" may be defined as: "Tending to move in or form a group with others of the same kind, as a herd, pack, or flock". Summarizing some other explanations (Heymer, 1982; Immelmann and Beer, 1989; Sarmiento, 2001; Hickman et al., 2002) to approach a more satisfying definition, gregariousness could be defined as the "habit of living in groups or herds of individuals of the same species that can be temporary (for refuge, new feeding sites or simply the sexual aggregations) or permanent".

In agreement with Currie and Eberth (2010), evidence for gregariousness in all the extinct taxa comes from five broad sources: (1) skeletal morphology, (2) bonebed assemblages, (3) tracksites, (4) phylogenetic inference, and (5) comparison with modern ecosystems. Whereas Lucas (2007) suggests that the evidences of group behaviour among dinosaurs are six: (1) anatomical display structures, characteristic of some groups of dinosaurs and that presumably allows the recognition of potential pairs or rivals within the group, (2) sexual dimorphism, which enables to distinguish between males and females within a group, (3) change in shape during the growth of some display structures, which would differentiate between juveniles and adults in a group, (4) mass-death bonebeds (although they are extremely debated in the literature), (5) nesting behaviour in some groups of dinosaurs and/ or parental care, and (6) some tracksites with parallel trackways with the same direction and speed.

Bone based data provide many examples of sites with aggregations of individuals both for Saurischia and Ornithischia (see references in Table 1). However, the best evidence of gregarious behaviour is currently inferred from the ichnological record, with a large amount of sites with signs of group behaviour (see references in Table 1).

In Spain, excluding La Rioja, there are other sites with ichnological evidence of gregarious behaviour in sauropods (Schulp and Brokx, 1999; López-Martínez et al., 1997-1998; Blanco et al., 2000b; Pérez-Lorente and Romero-Molina, 2001; Vila et al., 2006; Canudo et al., 2008; Castanera et al., 2011, 2012, in this issue), ornithopods (Piñuela et al., 2002) and theropods (Pérez-Lorente et al., 1997; Barco et al., 2005, 2006; Hernández Medrano et al., 2008; Pascual-Arribas and Hernández-Medrano, 2011).

La Rioja is the Spanish region with the largest number of dinosaur tracks (footprints) and also one of the most important areas in global fossil record. To date, more than 150 tracksites are documented and over 10,000 footprints have been studied, making this region an extraordinary area for palaeoichnological research. Furthermore, according to García-Ortiz and Díaz-Martínez (2008), the tracksites of La Rioja have contributed to the study on the behaviour of dinosaurs with several examples, and more specifically, the study of dinosaur trackway orientation patterns provides information of their possible herding or gregarious behaviour (García-Ortiz and Pérez-Lorente, 2012b) and even, of the palaeogeographic conditions (Moratalla y Hernán, 2010).

Here we explore all the contributions of the La Rioja area in the Cameros Basin for the study of dinosaur gregariousness. This exercise allows us to focus our perspective on the palaeoichnological evidence for gregarious dinosaurs in space

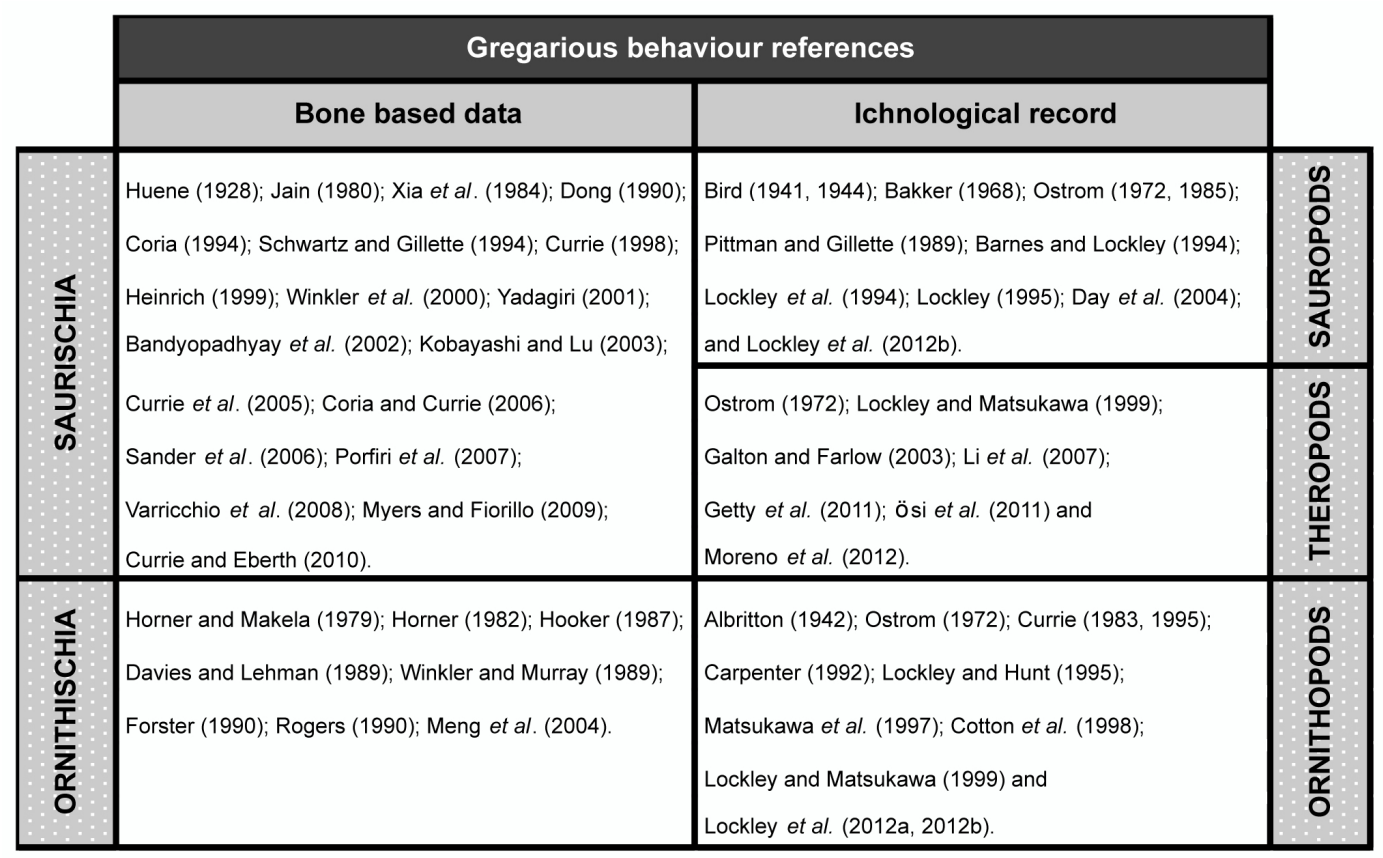

Table 1. Main references about gregarious behaviour based on bone data or on palaeoichnological record. 
$1 \mathrm{a}$

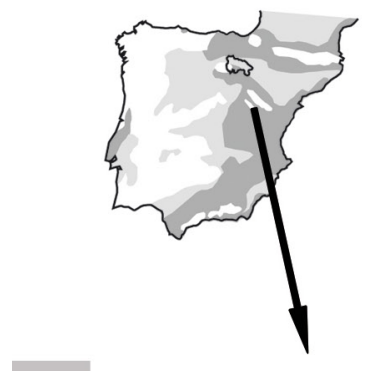

$1 \mathrm{~b}$

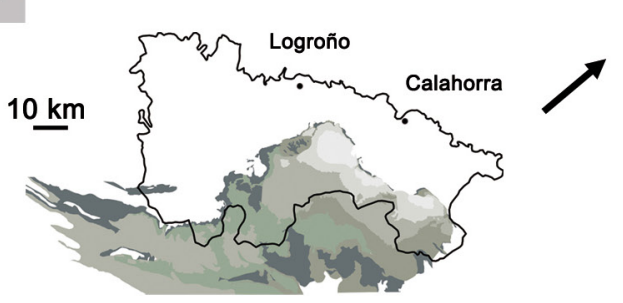

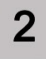

2

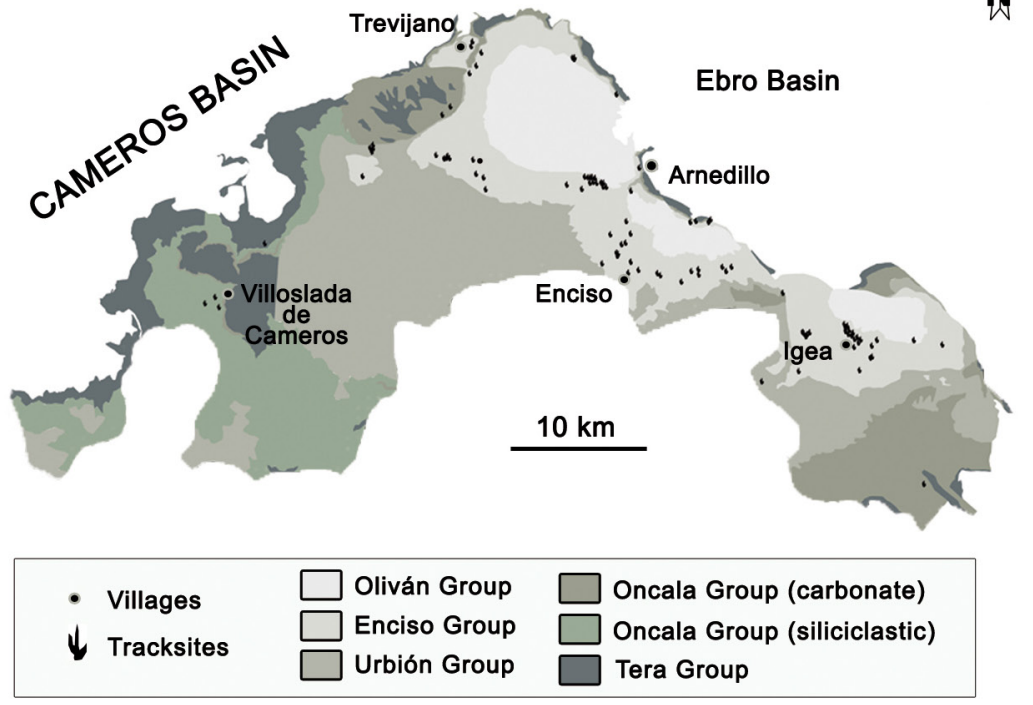

Fig. 1-. Geographical and geological location of the La Rioja area in the Cameros Basin (Lower Cretaceous, Spain). 1a) Simplified geologic map of the Iberian Peninsula. 1b) Geographical location of the Cameros Basin in the context of La Rioja Autonomous Region. 2) Tracksites and lithostratigraphic groups distribution into La Rioja area of the Cameros Basin, modified from Pérez-Lorente (2002).

and time, providing us to understand structure and dynamics of the populations in this area during the Early Cretaceous.

\section{Geographical and geological setting}

The Cameros Basin is located in the most northwestern Iberian Range, spanning territories belonging to the provinces of La Rioja, Soria and Burgos (Fig. 1.1). It is situated about 200 $\mathrm{km}$ to the south of the Mesozoic border of the Iberian plate and about $30 \mathrm{~km}$ to the current south-Pyrenean margin (DíazMartínez et al., 2010). It is one of the basins of the Mesozoic Iberian Rift System (Mas et al., 2002) and it is bounded by La Demanda Mountain Range (northwest), Tertiary Ebro Basin (north), Tertiary Duero and Almazán Basins (south) and Moncayo Mountain Range (east) (Díaz-Martínez, 2011).

The pre-rift Mesozoic stage is characterized by marine and continental Triassic rocks and marine Jurassic platform carbonates, similar to the rest of the Iberian Range (Aurell et al., 2002). The main phase of subsidence and deposition in the eastern Cameros Basin took place during the Late Jurassic and Early Cretaceous.

The Mesozoic Cameros Basin has a synclinal geometry, with maximum cumulative thickness in the central areas that decreases progressively toward the north and the south $(\mathrm{Ca}-$ sas et al., 2009). Mas et al. (1993) stated that there are 5000 meters of vertical cumulative thickness of sediment, mostly continental, from the Tithonian to the Albian.

Beuther (1966) and Tischer (1966) divide the basin succession into five lithostratigraphic units (Tera, Oncala, Urbión, Enciso and Oliván Groups) (Fig. 1.2) that are not syn- chronous throughout the region (Díaz-Martínez, 2011). We can summarize the data of Mas et al. (2002), Pérez-Lorente (2002, 2003a) and Díaz-Martínez et al. (2010) about these units in La Rioja area as follows:

- Tera Gr (Tithonian-Berriasian): detrital materials mainly of fluvial (braided and meandering) origin and some carbonates from shallow lakes. In La Rioja this Group generally crops out as coarse-grained sandstones and conglomerates; footprints have not been found on them. In Burgos, however, the group is composed of carbonate materials that show many dinosaur footprints.

- Oncala Gr (Berriasian): detrital material of meandering fluvial and lacustrine delta origin, as well as lacustrine carbonates. In La Rioja there are few footprints bearing sites in this Group, probably due to the small amount of cropping out surfaces. However, in Soria there are several tracksites. Pérez-Lorente (2002) divided this group into two members: siliciclastic and carbonate Oncala.

- Urbión Gr (upper Berriasian-upper Barremian): mainly detrital of fluvial (braided and meandering) origin and some carbonate material from shallow lakes. Footprints occur in many sites but less widespread in respect to the Enciso Gr.

- Enciso Gr (upper Barremian-upper Aptian): detrital and carbonate rocks (palustrine and lacustrine deposits). From this group comes the largest number of dinosaur footprints in the Basin.

- Oliván Gr (upper Aptian-lower Albian): detrital materials of meandering fluvial origin. The only cited site in La Rioja does no longer exist due to plundering. 

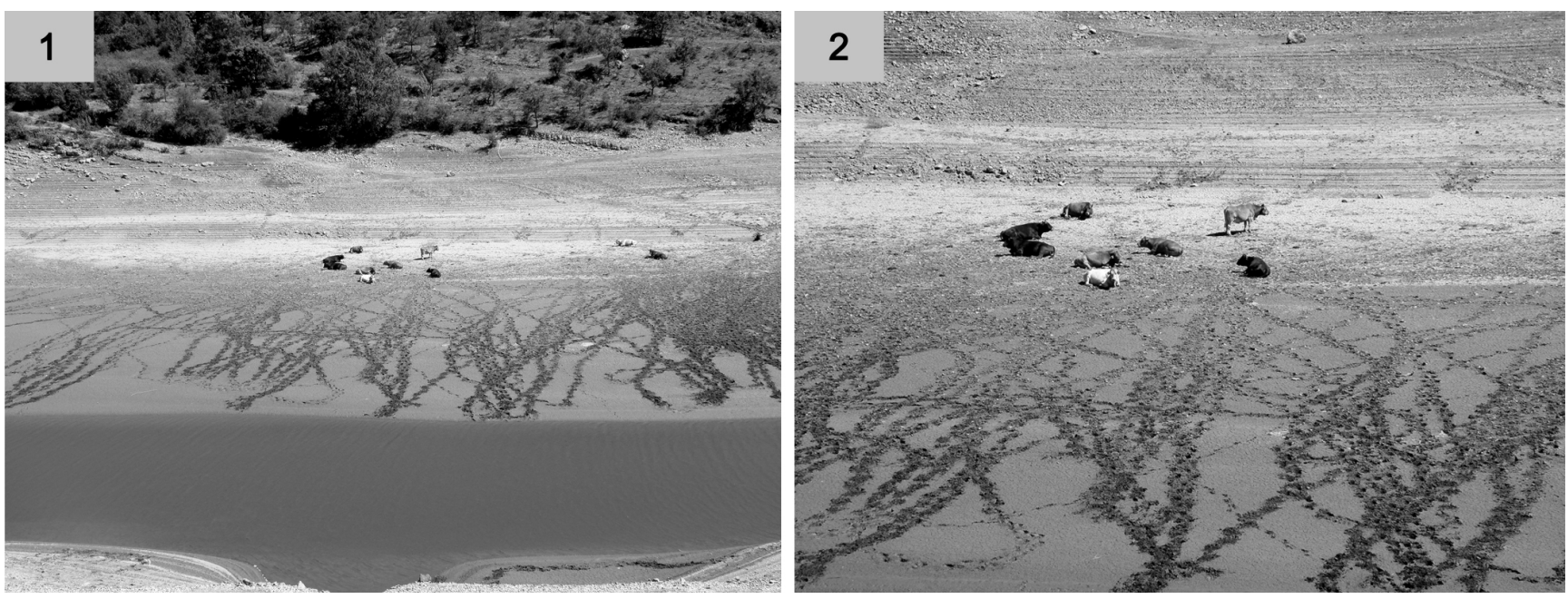

Fig. 2-. Current bovine traces at Mansilla reservoir (La Rioja, Spain). 1) Trackways along the edge of the reservoir, which acts as a physical barrier for their layout. 2) Photograph showing detail of the trackways where perpendicular patterns can be observed.

The studied tracksites are mainly located in the Enciso Gr, although some of them are placed in Urbión Gr and Oncala $\mathrm{Gr}$, as is described later in this paper. Some of these sites, geologically, are assigned to the Leza Formation, which is mainly composed of limestones, dolomites and marls but it also contains variable siliciclastic influence (conglomerates and sandstones) (Suárez-Gonzalez et al., 2013). The deposits of this formation have been mentioned in different works but it was not formally defined until the study of Mas et al. (1990) where it was assigned to Valanginian-Barremian age.

The age of the Leza Fm is controversial and ranges from Berriasian to Aptian according to the different proposals. It was initially assigned to the Enciso Gr together with the Jubera Fm and attributed to Valanginian-Barremian age (Mas et al., 1990), as mentioned before. On the other hand, Hernández Samaniego et al. (1990) dated it as Berriasian (Oncala Gr) using regional lithologic correlations and some charophyte data. Other studies described lateral relationship between the Leza Fm and the Enciso Gr describing the sporadic occurrence of dasycladales (calcareous algae) and foraminifers, considering it as Barremian-Aptian in age (Alonso and Mas, 1993; Suárez-González et al. 2010; Mas et al., 2002, 2011). Martín-Closas and Alonso (1998) used biostratigraphic and geologic data together with regional stratigraphic correlations and dated the Leza Fm as part of the Enciso Gr, (upper Barremian-lower Aptian). Doublet (2004) assigned it to the Oncala $\mathrm{Gr}$ on the basis of stratigraphic evidences interpreting it as part of the earlier Oncala Gr with a Berriasian-Valanginian age. He analysed the sedimentary facies dividing them into 11 facies associations organized in three main depositional environments: open lake, siliciclastic lacustrine shoreline and carbonate lacustrine shoreline (Doublet, 2004; p. 269). Clemente (2010), based on the stratigraphic position of the Leza Fm, the facies associations and the sedimentary environments, also assigned it to the Oncala Gr, lower-middle Berriasian in age. Recent studies
(Quijada et al., 2013; Suarez-González et al., 2013) with new biostratigraphic and sedimentological data again placed the Leza Fm in the Enciso Gr (upper Barremian-lower Aptian). Although it has been traditionally interpreted as lacustrine deposits with sporadic marine influence (Alonso and Mas, 1993), in this new study they interpreted this unit as deposited in a carbonate system of coastal-wetlands with both freshwater and sea-water influence, laterally related with alluvial deposits (Jubera Fm) and fluvio-lacustrine deposits (Enciso $\mathrm{Gr}$ ) towards the centre of the basin.

Finally, Moreno-Azanza et al. (2013) pointed out that the Leza Fm is at least Upper Berriasian in age in the area of Trevijano on the basis of the presence of the carophyte Globator maillardii nurrensis, that dates El Horcajo site as Upper Berriasian, (Globator maillardii nurrensis biozone, Riveline et al., 1996).

\section{Materials and methods}

The whole literature concerning dinosaur tracksites of the La Rioja area has been analysed as well as all the sites inventoried in the "Register of Cultural Heritage of the Government of La Rioja" with a total of 170 sites reviewed. Of these, and according to the information collected from the literature, only the sites in which any evidence of group behaviour was recorded have been considered in this work.

The analysed tracksites have been included in tables with relevant data like lithology, lithostratigraphic group to which they belong, etc. They have been cautiously classified according to the type of footprints and not depending on the type of trackmaker (Haubold, 1971; Pérez-Lorente, 2001; Pérez-Lorente et al., 2001). Bromley (1996) said that dinosaurs of the same species or even the same individual may produce different types of footprints according to their behaviour, and on the contrary, dinosaurs of different species can leave similar structures when they act in the same way. 
Nevertheless, we consider that, at least to major group level (e.g. Sauropods, Theropods, Ornitopods), well studied tracks can be quite confidently related to trackmakers, thus allowing to infer behaviours for the respective groups.

\subsection{Criteria for inferring gregarious behaviour from tracksites}

Lockley and Matsukawa (1999) suggested two important criteria in order to make a compelling case for gregarious behaviour based on tracks: multiple trackways of the same type on the same surface or within a very restricted stratigraphic interval, and secondly, parallel trackways indicating preferred direction of movement. Lockley (1991) also considered the depth of footprints as a determining proof, because footprints of similar sized animals walking together should have the same depth.

Lockley (1989) introduced another important criterion to determine gregariousness in dinosaurs: the "intertrackway spacing". This is a parameter for measuring the regularity of the separation between trackways in parallel sets. Nevertheless, Barco et al. (2006) remark upon the fact that the distance must be compatible with the size of the individuals of the group, and can be masked in aggregations with a large number of individuals moving in several waves.

However, the accumulation of numerous trackways of the same species in one site is not always a proof of gregariousness, since it could indicate the passage of different solitary individuals in different moments or the presence of a large number of individuals confined to an area without necessarily interacting as a herd (Ostrom, 1972). Besides the biological explanation, other possible hypothesis for non-random patterns in parallel trackways was postulated by Ostrom (1972): the presence of physical barriers that create natural corridors such as a shoreline. This reduces the possible directions of movement, condensing the trackways along certain pathways. Nevertheless, the existence of physical barriers may be ruled out in sites that contain trackways with perpendicular orientations. Lockley (1991) drew up an explanation which combines the alternatives given by Ostrom (1972) and suggested that parallel trackways can reflect gregarious behaviour affected by the physical constraints. However, the perpendicular orientations in trackways can be produced in environments with topographic barriers as occurs in actual ecosystems such as lakesides (authors' pers. obs.) (Fig. 2). There, some animals move to watering, leaving trackways perpendicular to the lakeshore, while others move along the lake leaving trackways parallel to the shore.

If we consider footprints of a single outcrop (e.g., footprints on the top of the same layer and assumably printed at the same time; both real footprints or homogeneous types of undertracks), the ichnocenosis or natural association of footprints that can show this type of behaviour can be associated with one of the following four types (Pérez-Lorente, 2001):

i) Tracks and trackways of the same ichnotype without a preferential orientation (accumulations/dinoturbations). This type is interpreted as the record of a place where many dinosaurs stepped because a parade of dinosaurs converged there or because constant environmental conditions were prolonged in time and this allowed the consecutive printing of track traces of solitary individuals or groups. Another possibility is that the place was suitable for the assembly of certain animals with individual behaviour for social or feeding reasons.

ii) Trackways of the same type proceeding in two-way direction. The most accepted interpretation is the presence of a physical barrier (steep slope or escarpment), of corridors (e.g., areas parallel to the shoreline) or of an untroubled way for the dinosaurs.

This may condition the passage of groups or individuals so this type of evidences needs a detailed study of each of their sets of trackways.

iii) Parallel trackways of the same type with the same direction. This is explained either by a physical barrier that conditioned and channeled the dinosaurs passing through or because the animals resolved to go there independently or in groups.

iv) Parallel trackways of different ichnogenera with the same direction. In this case, the interpretations depend on whether dinosaurs were herbivores, carnivores or both, and may be the result of passage of mixed groups, in case of different herbivores, or even an evidence of predatory behaviour.

This last kind of ichnocenosis is not strictly an evidence of social behaviour and, even less, of gregarious behaviour, because it is not an interaction among animals of the same species (García-Ortiz and Pérez-Lorente, 2012a). It may only be considered in the case of a group of dinosaurs being pursued by a predator, as suggested by Thulborn and Wade $(1979,1984)$ for the Lark Quarry site in the mid Cretaceous of Queensland - but see Romilio and Salisbury (2010) for a contrasting hypothesis and Thulborn (2011) for a reply.

In addition to the above examples, evidences will be divided in two groups: accumulations (dinoturbations) and parallel trackways. Within the sites characterized by sets of parallel trackways we differentiate the sites with only one direction of movement from those with two-way directions.

\section{Results}

A total number of 28 evidences of herding behaviour were studied in 25 different tracksites (Table 2). In La Rioja all the different ichnotypes (sauropod, ornithopod and theropod) are recorded (Pérez-Lorente, 2003a) and all the types of evidences are represented (Pérez-Lorente, 2001), as is indicated in Table 3.

\subsection{Parallel trackways}

12 evidences of parallel trackways were found, which represent the $42.86 \%$ of the total data of gregariousness studied. Nine of these are sets of parallel trackways with the same 


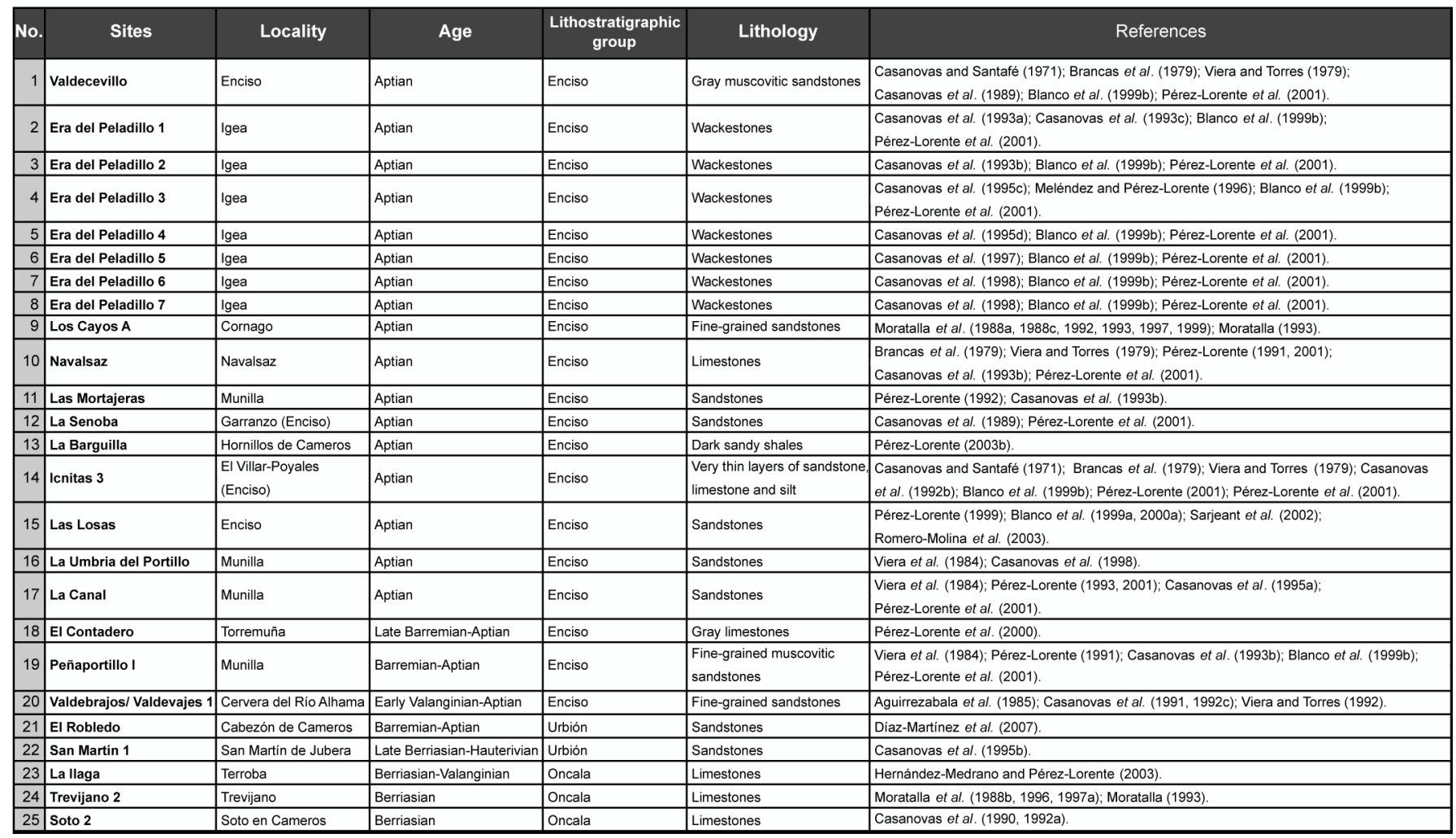

Table 2. List of studied tracksites detailing the locality to which they belong, their age, the lithostratigraphic group in which they are included, their lithology and the main references.

Table 3. Evidence of gregariousness registered in the studied tracksites of the La Rioja area in the Cameros Basin. Classification according to the ichnotype to which they belong (sauropod, ornithopod and theropod) and the type of evidence that they represent (accumulations or parallel trackways) (Pérez-Lorente, 2001). There are more than one evidence at some sites and that has been detailed as Gr. 1 and Gr. 2. ? indicates evidence of unknown bipedal ichnotype.

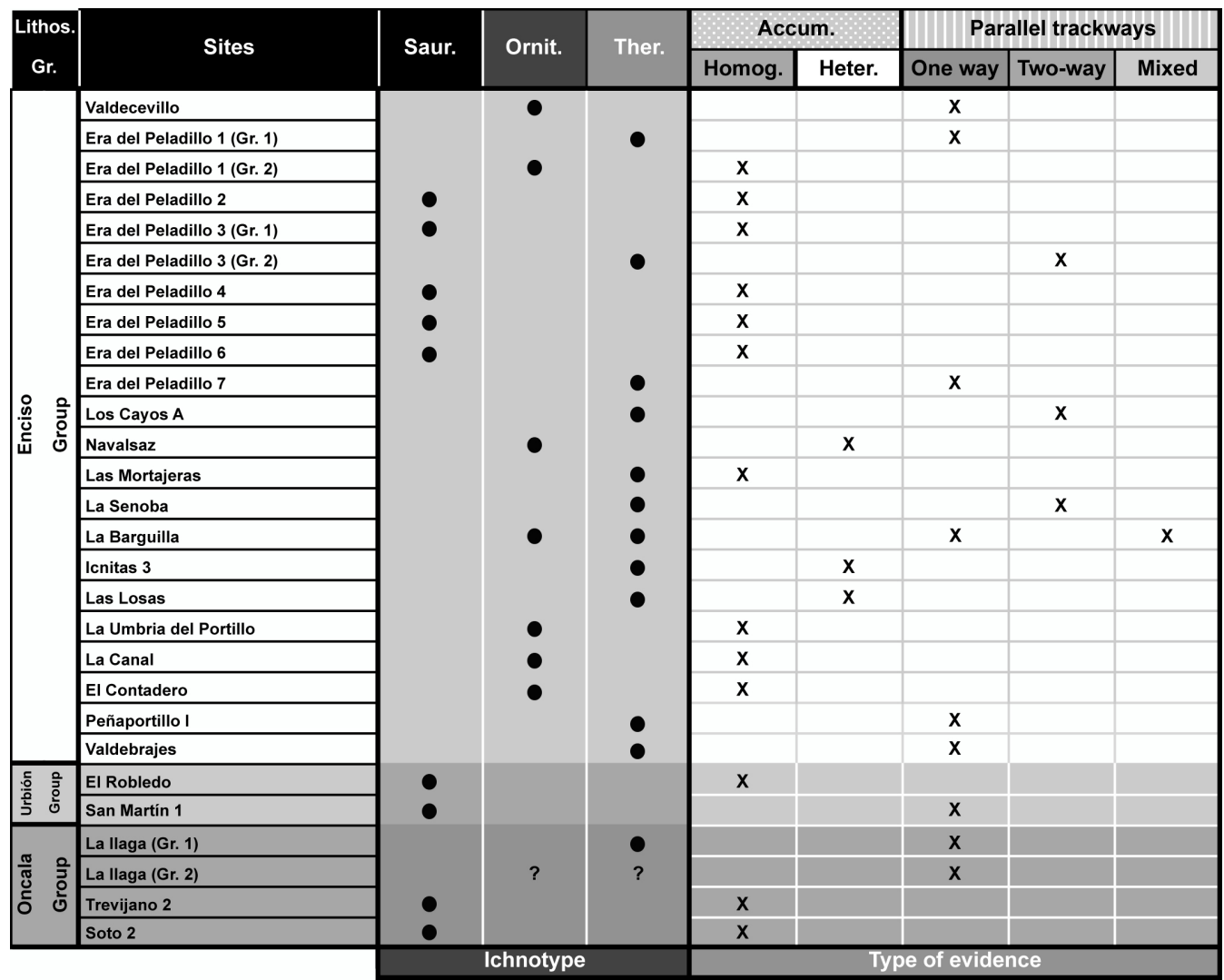




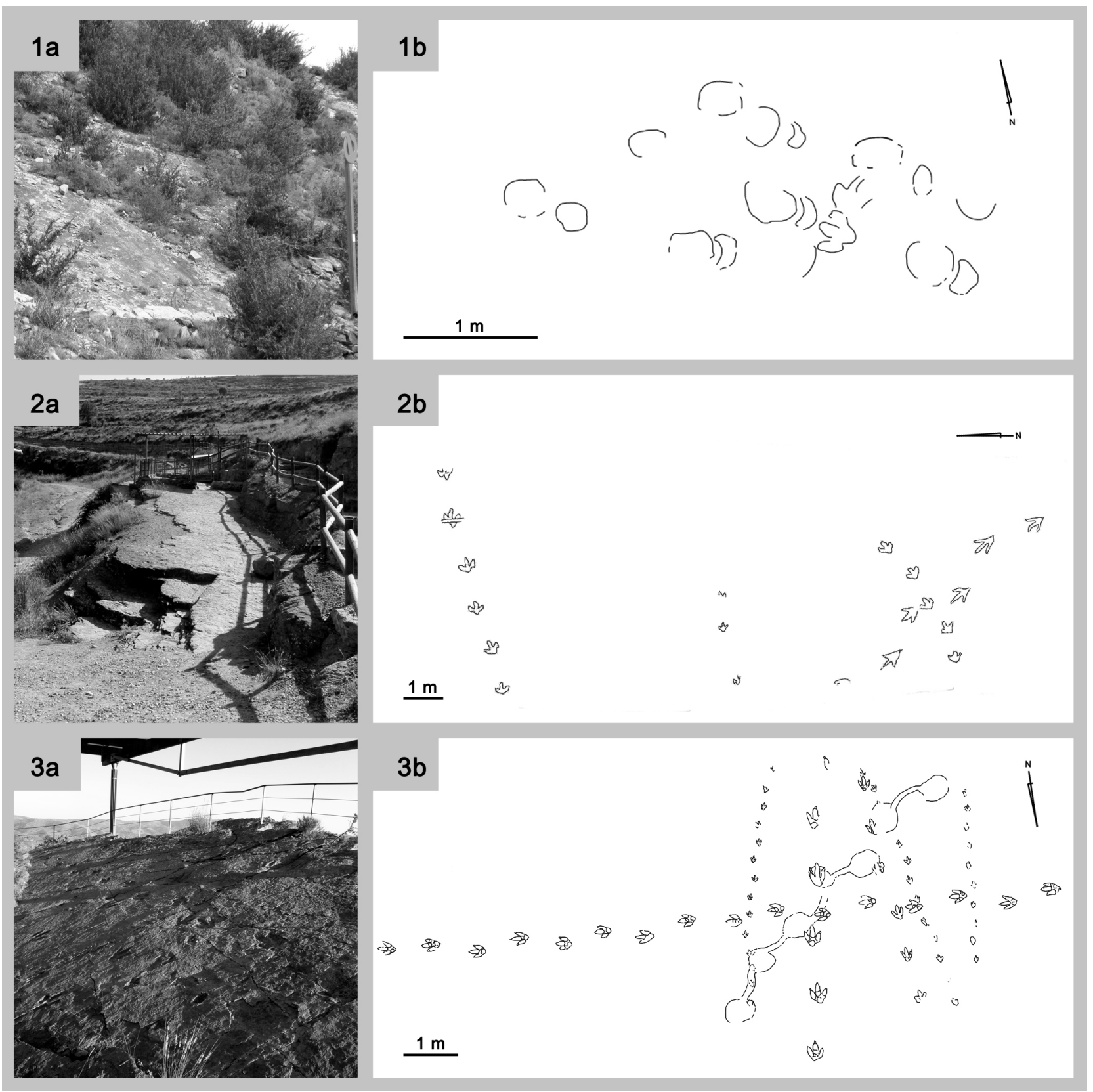

Fig. 3-. Examples of some representative tracksites with parallel trackways. 1. San Martin 1 tracksite, overview of the site (1a) and outline of the outcrop (1b) with two parallel sauropod trackways. 2. Barranco de Valdecevillo tracksite, overview of the site (2a) and partial outline of the outcrop (2b) with three parallel ornithopod trackways. 3. Peñaportillo I tracksite, overview of the site (3a) and outline of the outcrop (3b) with the five parallel theropod trackways.

direction and only three of them are groups with two-way direction (Table 3).

San Martin 1 (Fig. 3.1) is the only tracksite with this kind of evidence for sauropod footprints. In this site there are two short and incomplete parallel trackways with the same direction that have been attributed to medium-sized sauropods (Casanovas et al., 1995b). In ornithopod footprints there are two evidences, both examples related to sets of trackways with one-way direction. The Barranco de Valdecevillo site (Fig. 3.2) shows three parallel trackways with constant intertrackway spacing. In this site, it can be observed that the lateral trackways are composed of footprints larger than the intermediate one. It has been interpreted as a family group of ornithopod dinosaurs in which the adults walk keeping the juvenile between them to protect him (Casanovas and Santafé, 1971; Brancas et al., 1979; Viera and Torres, 1979; Casanovas et al., 1989; Blanco et al., 1999b; Pérez-Lorente et al., 2001). The second example is La Barguilla site where there are two parallel ornithopod trackways and the trackway of a theropod that is parallel to the other two trackways even during their change in direction. This has been interpreted as a possible hunting scene (Pérez-Lorente, 2003b). In Table 3 this site has been reflected in a specific column called "mixed parallel trackways". 
In theropod footprints there are eight evidences of parallel trackways, five of them (Era del Peladillo 1 and 7, Peñaportillo I, La Ilaga and Valdebrajes; see references in Table 2) have trackways with the same direction and the other three (Era del Peladillo 3, Los Cayos A and La Senoba; see references in Table 2) have sets of trackways with two-way direction. In all cases, except Peñaportillo I, there are sets of homogeneous trackways, with similar sizes of the footprints and so of the individuals who made the traces. However, in Peñaportillo I (Fig. 3.3) there are five parallel trackways. Two of them are of larger size than the other three. The different interpretations span from the idea of a family group to two sets of different sized dinosaurs that crossed this place at different times (Viera et al., 1984; Pérez-Lorente, 1991; Casanovas et al., 1993b; Blanco et al., 1999b; Pérez-Lorente et al., 2001).

In La Ilaga site there is a second group of parallel trackways with the same direction, but it has been attributed to undetermined bipedal dinosaurs (Hernández Medrano and Pérez-Lorente, 2003) (Table 3).

\subsection{Accumulations}

16 evidences of accumulations have been found and this represents the $57.14 \%$ of the total. Of these, 13 correspond to homogeneous accumulations, which are made by individuals of the same size (class age), and only three are heterogeneous accumulations, attributed to mixed age groups (Table 3 ).

In sauropod footprints eight examples of accumulations have been found (La Era del Peladillo 2, 3, 4, 5 and 6, El Robledo, Trevijano 2 and Soto 2; see references in Table 2; Fig. 4), and all of them are homogeneous. In this paper the outcrops of La Era del Peladillo have been identified independently ( 1 to 7 ) because in that way they have been published (see references in Table 2); indeed all represent a unique tracksite and a unique herd.

Five evidences concern ornithopod footprints: four of them (La Era del Peladillo 1, Umbria del Portillo, La Canal and El Contadero; see references in Table 2) are homogeneous accumulations and just one (Navalsaz; Brancas et al., 1979; Viera and Torres, 1979; Pérez-Lorente, 1991, 2001; Casanovas et al., 1993b; Pérez-Lorente et al. 2001) is a heterogeneous accumulation. For La Era del Peladillo 1 (Fig. 4.2), the accumulation of ornithopod footprints is attributed to a herd, which stopped in that place and was flanked by two individuals who left trackways parallel to the group direction (Casanovas et al., 1993a, 1993c; Blanco et al., 1999b; PérezLorente et al., 2001).

Only three examples have been documented for theropod footprints: Las Mortajeras (Fig. 4.3), interpreted as a homogeneous accumulation and Las Losas and Icnitas 3, which are heterogeneous ones. In these three cases, parallel trackways with the same direction are distinguishable among the footprints accumulations.

\section{Discussion}

The most accepted evidence of a possible herding behaviour in dinosaurs is represented by parallel trackways but they should fulfill certain conditions to be considered as gregarious behaviour. The same direction of the trackways, the intertrackway space, the speed values, the depth of the footprints, the width of the herd and the evidence that all the members of the herd maintain the same gait are data used to infer this type of behaviour (Castanera et al., 2012).

In general, it is possible to recognize group behaviour because of the presence of footprints of the same type, assumably printed at the same time. Therefore, it is essential to know if the area of study is the surface on which the selected true tracks were printed, or if they are undertracks. Moreover it would be necessary to know if they are relatable in time or even if there are repeated behaviour patterns (e.g., nesting areas; Chiappe et al., 2005). Then, it is necessary to make a careful analysis of temporal sequences and spatial position of the footprints, both in the printed surface and in the entire studied area. However, these criteria are not exclusive for all sites, but require a careful analysis of the footprints and their comparison with actual animal behaviour.

As far as accumulations are concerned, opinions are widely diversified. Bird (1944) wrote about a place to "parade" where dinosaurs converged, stepping repeatedly on the same tracks until they appear as craters in the mud. Other authors stated that dinoturbations are not necessarily evidence of gregariousness but of group activity (Ostrom, 1972). The fact that accumulations abound in the literature is because they are taken into consideration as evidence of gregariousness, especially for certain types of dinosaurs such as sauropods. However, it is matter of opinion because a very dinoturbated surface is not indicative of a large number of individuals but rather of concentrated vital activity. An area frequented by the same individual for food or habitat reasons may have accumulations of footprints of the same characteristics and similar trackway patterns, and it is not indicative of herding behaviour yet. To sum up, it is considered a hazardous hypothesis to explain these cases as gregariousness behaviour as well as to indicate they are not.

As regards sauropod footprints, evidences in La Rioja area are mostly homogeneous accumulations (Table 3 ) with medium-sized footprints on highly dinoturbated surfaces. Small footprints of this ichnotype were not recorded and there is just one evidence of two parallel sauropod trackways in San Martin 1 (Casanovas et al., 1995b) (Fig. 3.1). This datum is not conclusive because the trackways are short, incomplete and badly preserved; anyhow they belong to medium-sized sauropods too. The presence of evidences of gregariousness with homogeneous groups would support the hypothesis of Myers and Fiorillo (2009), who stated that sauropods could be segregated in small herds according to age. In La Rioja 

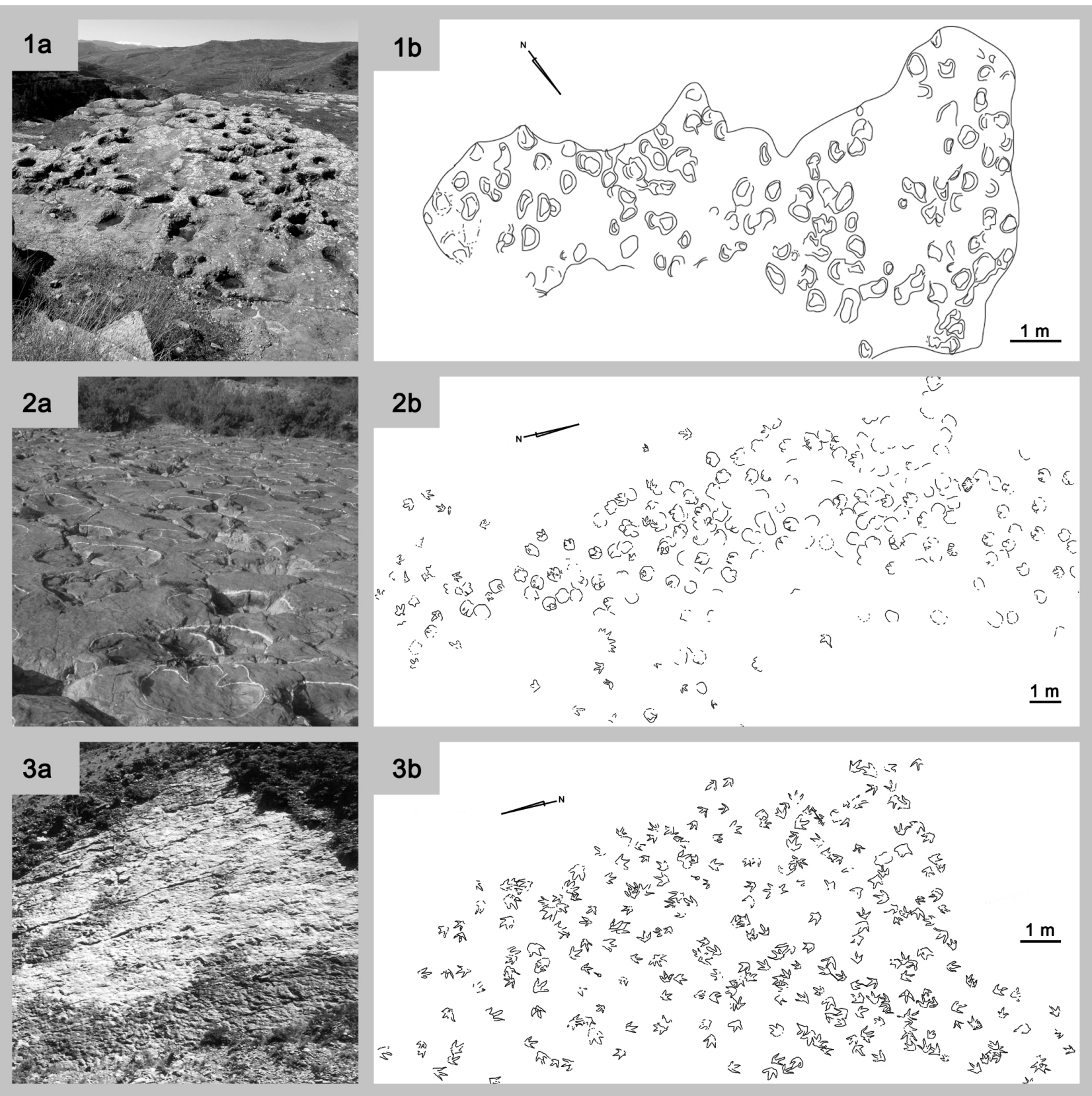

Fig. 4-. Some representative tracksites as example of accumulations. 1. Soto 2 tracksite, overview of the site (1a) and outline of the outcrop (1b) with the dinoturbation supposedly created by a herd of sauropods. 2. La Era del Peladillo 1 tracksite, overview of the site (2a) and partial outline of the outcrop (2b), which represents the accumulation of ornithopod footprints produced by a group of ornithopods. 3. Las Mortajeras tracksite, overview of the site (3a) and outline of the outcrop (3b).

most sauropod trackways are isolated, probably due either to the small size of most sites or to an individual behaviour.

Few data concern parallel trackways of ornithopod footprints. On the contrary there are several examples of homogeneous accumulations (i.e. belonging to individuals of medium-large size; more than $25 \mathrm{~cm}$ foot length; Thulborn, 1990) and one of heterogeneous accumulation (in Navalsaz; Brancas et al., 1979; Viera and Torres, 1979; Pérez-Lorente, 1991; 2001; Casanovas et al., 1993b; Pérez-Lorente et al. 2001); both types are interpreted as evidence of gregariousness (Table 3). Above has been discussed that this kind of evidence is so much questioned. However, there are examples like La Era del Peladillo 1 (Casanovas et al., 1993a; 1993c; Blanco et al., 1999b; Pérez-Lorente et al., 2001), with a "band" accumulation of large footprints (Fig. 4.2) probably made by a big herd and two trackways parallel to it, with same movement direction and a regular separation distance, which are difficult to explain if not as evidence of herd behaviour. Furthermore, there are also examples of associations of trackways with juveniles and adults (Casanovas and Santafé, 1971; Brancas et al., 1979; Viera and Torres, 1979; Casanovas et al., 1989; Blanco et al., 1999b; Pérez-Lorente et al., 2001) that would indicate parental care of some ornithopods, at least during certain life stages and a higher diversity in the group com- 
position of these animals. This supports the hypothesis suggested by Matsukawa et al. (1999, p. 49) that juveniles are usually accompanied by adults or subadults (not together) or by adults and subadults together (in the same group).

The dataset of theropod footprints varies more. There are few papers concerned to theropod track accumulations, perhaps because few authors dare to say that examples of accumulations really indicate gregarious behaviour for theropods. In our study area we can list only two heterogeneous accumulation examples (i.e., Las Losas and Icnitas 3) and one homogeneous (i.e., Las Mortajeras; see Figure 4.3) (Table 3). However, evidences of parallel trackways in one-way or two-way direction are abundant. The most supported explanation for two-way direction parallel trackways is the presence of a physical barrier that affected the passage of individuals (Ostrom, 1972). About parallel trackways with the same direction, there is evidence of small groups (usually no more than ten individuals) with constant intertrackway spaces (e.g. Era del Peladillo 1 and Valdebrajes) (Table 3) or even possible mixed-age groups (Peñaportillo I) (Fig. 3). Moreover, from the La Rioja area, there are no examples of gregarious behaviour with large theropod footprints. Most are examples of small to medium size footprints (less than 25 $\mathrm{cm}$ foot length), in separated homogeneous groups or even in mixed size groups. This could be explained by a correlation between the increase of size in theropods and the reduction of their gregarious behaviour, although recent studies with bonebed assemblages and some tracksites argue exactly the contrary (Roach and Brinkman, 2007; Currie and Eberth, 2010).

In general, the shortage of small footprints, especially in ornithopods and sauropods, may be due to the fact that the environments frequented by juveniles of these herbivorous dinosaurs were different, or because they are not recorded for preservational reasons (e.g., high probability to disappear because of dinoturbation; rapid early growth rates; reduced potential for imprinting due to small size; Lockley, 1991; Horner, 1992; Matsukawa et al., 1999).

Almost all the tracksites are from the Enciso Gr, which palaeoenvironment is interpreted as a lacustrine or palustrine system. There are no in-depth lithological studies of all sites, which makes difficult to infer any relation between the gregarious behaviour of some dinosaurs and the specific environment. Doublet (2004) mentioned some sites as examples of some specific facies. This is the case of La Era del Peladillo, Las Losas and El Villar-Poyales (Icnitas 3) sites, associated with emersive lacustrine carbonates facies where tracks are normally associated with desiccation surfaces. What can be observed it is that sauropod groups appear in carbonate lithologies (Table 2), which means areas near lakes with slightly higher depth.

The Urbión Gr is interpreted as fluvial (braided and meandering) environments and all the sites with herding behaviour from this group show just sauropod footprints, accumulations (Díaz-Martínez et al., 2007) and parallel trackways (Casano- vas et al., 1995b), all related to siliciclastic sediments. However, this lithostratigraphic group, in this area of the Cameros Basin, crops out in too small amount for allowing the inference of relationships between the type of behaviour and the depositional environment.

The Oncala Gr is also scarcely represented among the sites of this area of the Cameros Basin and it is interpreted as a meandering fluvial and lacustrine delta system. Evidences of gregariousness in this group are mainly highly dinoturbated surfaces with sauropod footprints (Moratalla et al., 1988b, 1996, 1997; Casanovas et al., 1990; 1992a; Moratalla, 1993), but there are also two groups of parallel trackways of bipedal dinosaurs (Hernández Medrano and Pérez-Lorente, 2003). All these sites are characterized by carbonates but, as occurs with the Urbión Gr, the Oncala Gr does not crop out so much to infer any kind of relation between gregariousness and environment.

To sum up, there are not complete sedimentological studies of each of the sites from this part of the Cameros Basin, and this makes essential a more detailed study of this aspect in order to infer possible relationships between the behaviour and the environment. Moreover, it will be necessary to complete and compare all the collected data with the evidences found in Burgos and Soria areas of the Cameros Basin.

\section{Conclusions}

La Rioja area in the Cameros Basin has provided 25 tracksites with 28 different data evidence about gregarious behaviour in dinosaurs in which can be observed that groups of parallel trackways are as abundant as accumulations.

Parallel trackways are the most accepted evidence of gregarious behaviour. In our studied area, there are sets of parallel trackways of the three mentioned ichnotypes being the most common evidence the parallel theropod trackways and the less common evidence, the parallel sauropod trackways with just one example of two parallel trackways.

Accumulations are the most discussed data but, in the case of sauropods, they are almost the only kind of evidence of gregarious behaviour in this area. For ornithopod footprints, there are examples of accumulations and associated parallel trackways that have been interpreted as those left by individuals that flanked the herd. In theropods, accumulations are frequent but a peculiarity is that in many cases parallel trackways can be distinguished inside.

According to these data, sauropods could move in herds of homogeneous age as postulated by other authors. Ornithopod footprints show diversity in the group composition in number and age. With regard to the theropod footprints, it can be observed that there are mainly homogeneous size groups with examples of tracks from small to medium size individuals, and no one of big size.

This provides key information about the ecology of these animals through the knowledge of how they behaved in these environments, including data like the herd size and composi- 
tion, the herd structure or the relative position of the individuals when moving.

We conclude therefore that gregarious behaviour was probably common among certain groups of dinosaurs from the Early Cretaceous or at least it was usual during specific moments of their lives, as occurs in actual terrestrial ecosystems.

\section{Acknowledgements}

EGO acknowledges University of León for the financial support for the research of which is beneficiary in order to develop her doctoral thesis. We also thank Jose Ignacio RuízOmeñaca (MUJA), Esperanza Fernández-Martínez (University of León) and Ignacio Díaz-Martínez (University of La Rioja) for their comments and their bibliographical support and Cristina Guardamino in revising the English text. We specially express our gratitude to the referees, Umberto Nicosia and Xabier Pereda Suberbiola, and the editors for their comments and suggestions, which have improved the manuscript.

\section{References}

Aguirrezabala, L.M., Torres, J.A., Viera, L.I. (1985): El Weald de Igea (Cameros-La Rioja). Sedimentología, Bioestratigrafía y Paleoicnología de grandes reptiles (Dinosaurios). Munibe, 37: 111-138.

Albritton, C.C. (1942): Dinosaur tracks near Comanche, Texas. Field and Laboratory, 10: 160-181.

Alonso, A., Mas, J.R. (1993): Control tectónico e influencia del eustatismo en la sedimentación del Cretácico inferior de la cuenca de Los Cameros. Cuadernos de Geología Ibérica, 17: 285-310.

Aurell, M., Meléndez, G., Olóriz, F., Bádenas, B., Caracuel, J.E., Martínez, J.C., Goy, A., Linares, A., Quesada, S., Robles, S., RodríguezTovar, F.J., Rosales, I., Sandoval, J., Suárez de Centi, C., Tavera, J.M., Valenzuela, M. (2002): “Jurassic”. In: W. Gibbons and Moreno (eds.), The Geology of Spain. Londres, The Geological Society: 213-254.

Bakker, R.T. (1968): The superiority of dinosaurs. Discovery, 3(2): 11-22.

Bandyopadhyay, S., Roy-Chowdhury, T.K., Sengupta, D.P. (2002): Taphonomy of some Gondwana vertebrate assemblages of India. Sedimentary Geology, 147: 219-245. doi: 10.1016/S0037-0738(01)00198-1.

Barco, J.L., Canudo, J.I., Ruiz-Omeñaca, J.I. (2005): Gregarious behaviour in theropod dinosaurs inferred from new data on Therangospodus oncalensis from the Berriasian Fuentesalvo tracksite (Villar del Río, Soria, Spain). Abstract Book-International Symposium on dinosaurs and other vertebrates Palaeoichnology (October 4-8th 2005) Fumanya, Barcelona: 38-40.

Barco, J.L., Canudo, J.I., Ruiz-Omeñaca, J.I. (2006): New data on Therangospodus oncalensis from the Berriasian Fuentesalvo tracksite (Villar del Río, Soria, Spain): an example of gregarious behaviour in theropod dinosaurs. Ichnos, 13: 237-248. doi: 10.1080/10420940600843682

Barnes, F.A., Lockley, M.G. (1994): Trackway evidence for social sauropods from the Morrison Formation, Eastern Utah (USA). GAIA, 10: $37-42$.

Beuther, A. (1966): Geologische Untersuchungen in Wealdenund Utrillas Schichten in Westteil der Sierra de los Cameros (Nordwestliche Iberische Ketten). (Spanien). Beihefie zum Geologischen Jahrbuch, 55: 103-121.

Bird, R.T. (1941): A dinosaur walks into the museum. Natural History, 43: $254-261$
Bird, R.T. (1944): Did Brontosaurus ever walk on land? Natural History, 53: 61-67.

Blanco, M.I., Caro, S., López, A., Pérez-Lorente, F., Requeta, E., Romero, M. (1999a): The Las Losas paleoichnological site. In: IV European workshop on Vertebrate Paleontology, Albarracín Junio 1999: p. 26.

Blanco, M.I., Caro, S., López, A., Pérez-Lorente, F., Requeta, E., Romero, M. (2000a): El yacimiento de icnitas de dinosaurio del Cretácico Inferior de Las Losas (Enciso, La Rioja, España). Zubía, 18: 97-138.

Blanco, M.I., Caro, S., Pérez-Lorente, F., Requeta, E., Romero, M. (1999b): Paleo-ichnological Sites in la Rioja. Some Examples in Enciso, Igea and Munilla. In: G. Melendez, C. Soria-Llop (eds.). The Geological and Paleontological heritage of central and eastern Iberia (Iberian Range, Spain). III International Symposium proGEO on the Conservation of the Geological Heritage, 4: 51-74.

Blanco, M., Caro, S., Pérez-Lorente, F., Requeta, L.E., Romero, M. (2000b): Un Nuevo yacimiento con icnitas saurópodas en la Cordillera Ibérica. Galve (Teruel). Geogaceta, 28: 23-26.

Brancas, R., Martínez, J., Blaschke, J. (1979): Huellas de dinosaurio de Enciso. Ed. Gonzalo de Berceo. Diputación de Logroño: 96 p.

Bromley, R.G. (1996): Trace Fossils, 2nd edition. Chapman and Hall, London (ed.): $361 \mathrm{p}$.

Canudo, J.I., Pérez-Lorente, F., Badiola, A., Barco, J.L., CruzadoCaballero, P., Díaz- Martínez, I., Gasca, J.M., Gómez-Fernández, D., Moreno-Azanza, M., Herrero Gascón, J. (2008): Evidencia de gregarismo en pequeños dinosaurios saurópodos del TitónicoBerriasiense (Formación Villar del Arzobispo, Galve, Teruel). In: J.I. Ruiz-Omeñaca, L. Piñuela, J.C. García-Ramos (eds.), Libro de resúmenes. XXIV Jornadas de la Sociedad Española de Paleontología. Museo del Jurásico de Asturias (MUJA), Colunga, 15-18 de octubre de 2008: 23-24.

Carpenter, K. (1992): Behavior of hadrosaurs as interpreted from footprints in the "Mesaverde" Group (Campanian) of Colorado, Utah, and Wyoming. Rocky Mountain. Geology, 29: 81-96.

Casanovas, M.L., Ezquerra, R., Fernández, A., Montero, D., Pérez-Lorente, F., Santafé, J.V., Torcida, F., Viera, L. (1995a): El yacimiento de La Canal (Munilla, La Rioja. España). La variación de la velocidad en función del tamaño del pie de los ornitópodos. Zubía, 13: 55-81.

Casanovas, M.L., Ezquerra, R., Fernández, A., Pérez-Lorente, F., Santafé, J.V. (1990): Huellas de dinosaurio en Soto de Cameros, La Rioja (España). Zubia, 8: 49-71.

Casanovas, M.L., Ezquerra, R., Fernández, A., Pérez-Lorente, F., Santafé, J.V., Torcida, F. (1992a): Un grupo de saurópodos en el yacimiento de Soto 2. La Rioja (España). Zubía, 10: 45-52.

Casanovas, M.L., Ezquerra, R., Fernández, A., Pérez-Lorente, F., Santafé, J.V., Torcida, F. (1993a): Huellas de dinosaurios palmeados y de terópodos en la "Era del Peladillo". Igea (La Rioja). Zubía, 11: 14-53.

Casanovas, M.L., Ezquerra, R., Fernández, A., Pérez-Lorente, F., Santafé, J.V., Torcida, F. (1993b): Icnitas de dinosaurios. Yacimientos de Navalsaz, Las Mortajeras, Peñaportillo, Malvaciervo y la Era del Peladillo 2, (La Rioja, España). Zubía Monográfico, 5: 9-133.

Casanovas, M.L., Ezquerra, R., Fernández, A., Pérez-Lorente, F., Santaté, J.V., Torcida, F. (1993c): Tracks a herd of webbed Ornithopoda and other footprint found in the same site (Igea, La Rioja, Spain). Revue de Paléobiologie, 7: 29-36.

Casanovas, M.L., Ezquerra, R., Fernández, A., Pérez-Lorente, F., Santafé, J.V., Torcida, F. (1995b): Dos nuevos yacimientos de icnitas de dinosaurios en La Rioja y en la provincia de Soria (España). Coloquios de Paleontología, 47: 9-23.

Casanovas, M.L., Ezquerra, R., Fernández, A., Pérez-Lorente, F., Santafé, J.V., Torcida, F. (1995c): Huellas de dinosaurio en la era del Peladillo 3 (La Rioja, España); primera nota. Zubía, 13: 83-101.

Casanovas, M.L., Ezquerra, R., Pérez-Lorente, F., Santafé, J.V., (1992b): Revisión del yacimiento "Icnitas 3" de huellas de dinosaurio (Enciso, La Rioja, España). Zubía, 10: 31-44. 
Casanovas, M.L., Fernández, A., Pérez-Lorente, F., Santafé, J.V. (1989): Huellas de dinosaurio de La Rioja. Yacimientos de Valdecevillo, La Senoba y de la Virgen del Campo. Instituto de Estudios Riojanos. Ciencias de la Tierra, 12: $190 \mathrm{p}$.

Casanovas, M.L., Fernández, A., Pérez-Lorente, F., Santafé, J.V. (1991): Dinosaurios coelúridos gregarios en el yacimiento de Valdevajes ( $\mathrm{La}$ Rioja, España). Revista Española de Paleontología, 6(2): 177-189.

Casanovas, M.L., Fernández, A., Pérez-Lorente, F., Santafé, J.V. (1992c): Icnitas de dinosaurios en Valdevajes (La Rioja). Nota de contrarréplica. Revista Española de Paleontología, 7(1): 97-99.

Casanovas, M.L., Fernández, A., Pérez-Lorente, F., Santafé, J.V. (1995d): La era del Peladillo 4 (La Rioja, España). Ciencias de la Tierra, 18: 45-53.

Casanovas, M.L., Fernández, A., Pérez-Lorente, F., Santafé, J.V., Torcida, F. (1997): Ornithopod, theropod and sauropod tracks in the Peladillo 5 era, La Rioja, Spain. Zubía, 15: 229-246.

Casanovas, M.L., Fernández, A., Pérez-Lorente, F., Santafé, J.V. (1998): Ocho nuevos yacimientos de huellas de dinosaurio. Zubía, 16: 117152.

Casanovas, M.L., Santafé, J.V. (1971): Icnitas de reptiles mesozoicos en la provincia de Logroño. Acta Geológica Hispánica, VI, 5: 139-142.

Casas, A.M., Villalaín, J.J., Soto, R., Gil-Imaz, A., del Río, P., Fernández, G. (2009): Multidisciplinary approach to an extensional syncline model for the Mesozoic Cameros Basin (N Spain). Tectonophysics, 470: 3-20. doi: 10.1016/j.tecto.2008.04.020

Castanera, D., Barco, J.L., Díaz-Martínez, I., Herrero Gascón, J., PérezLorente, F., Canudo, J.I. (2011): New evidence of a herd of titanosauriform sauropods from the lower Berriasian of the Iberian range (Spain). Palaeogeography, Palaeoclimatology, Palaeoecology, 310: 227-237. doi: 10.1016/j.palaeo.2011.07.015.

Castanera, D., Vila, B., Razzolini, N., Dos Santos, V.F., Pascual, C., Canudo, J.I.. (2012): Gregarious behaviour inferred from sauropod footprints in the Iberian Peninsula. In: C. Martínez-Pérez, M. Furió, A. Santos-Cubedo (eds.). Paleodiversity and Paleoecology of Iberian Ecosystems. Sot de Chera, Valencia: 61-62.

Castanera, D., Vila, B., Razzolini, N., Dos Santos, V.F., Pascual, C., Canudo, J.I.. (in this issue): Sauropod trackways of the Iberian Peninsula: palaeoetological and palaeoenvironmental implications. Journal of Iberian Geology.

Chiappe, L.M., Jackson, F., Coria, R.A., Dingus, L. (2005): Nesting titanosaurs from Auca Mahuevo and adjacent sites: understanding sauropod reproductive behavior and embryonic development. In: K.A. Curry Rogers, J.A. Wilson (eds.). The sauropods. Evolution and paleobiology. University of California Press, Berkeley and Los Angeles: 285-302.

Clemente, P. (2010): Review of the Upper Jurassic-Lower Cretaceous Stratigraphy in Western Cameros basin, Northern Spain. Revista de la Sociedad Geológica de España, 23(3-4): 101-143.

Coria, R.A. (1994): On a monospecific assemblage of sauropod dinosaurs from Patagonia: implications for gregarious behavior. GAIA, 10: 209-213.

Coria, R.A., Currie, P.J. (2006): A new carcharodontosaurid (Dinosauria, Theropoda) from the Upper Cretaceous of Argentina. Geodiversitas, 28(1): 71-118.

Cotton, W.D., Cotton, J.E., Hunt, A.P. (1998): Evidence for social behavior in ornithopod dinosaurs from the Dakota Group of northeastern New Mexico, U.S.A. Ichnos, 6: 141-149. doi: 10.1080/10420949809386445.

Currie, P.J. (1983): Hadrosaur trackways from the Lower Cretaceous of Canada. Acta Palaeontologica Polonica, 28: 63-73.

Currie, P.J. (1995): Ornithopod trackways from the Lower Cretaceous of Canada. In: W.A.S. Sarjeant (ed.), Vertebrate Fossils and the Evolution of Scientific Concepts. Gordon and Breach Newark, NJ, USA: 431-443.
Currie, P.J. (1998): Possible evidence of gregarious behavior in tyrannosaurids. GAIA, 15: 271-277.

Currie, P.J., Eberth, D.A. (2010): On gregarious behavior in Albertosaurus. Canadian Journal of Earth Sciences, 47: 1277-1289. doi: 10.1139/E10-072.

Currie, P.J., Trexler, D., Koppelhus, E.B., Wicks, K., Murphy, N. (2005): An unusual multiindividual tyrannosaurid bonebed in the Two Medicine Formation (Late Cretaceous, Campanian) of Montana (USA). In: K. Carpenter (ed.), The Carnivorous Dinosaurs. Indiana University Review, Bloomington: 313-324.

Davies, K.L., Lehman, T.M. (1989): The WPA Quarries. In: A.B. Busbey III, T.M., Lehman (eds.), Vertebrate Paleontology, Biostratigraphy and Depositional Environments, Latest Cretaceous and Tertiary, Big Bend Area, Texas. Society of Vertebrate Paleontology, 49th Annual Meeting Fieldtrip Guidebook, Austin: 32-42.

Day, J.J., Norman, D.B., Gale, A.S., Upchurch, P., Powell, H.P. (2004): A Middle Jurassic dinosaur trackway site from Oxfordshire, UK. Palaeontology, 47(2): 319-348. doi: 10.1111/j.0031-0239.2004.00366.x.

Díaz-Martínez, I. (2011): Generalidades sobre las icnitas ornitópodas de La Rioja (Cuenca de Cameros, España). Zubía, 29: 61-84.

Díaz-Martínez, I., García-Ortiz de Landaluce, E., Ibisate, R., PérezLorente, F. (2007): Nuevas aportaciones al registro paleoicnológico en Cabezón de Cameros (La Rioja. España). Geogaceta, 42: 87-90.

Díaz-Martínez, I., García-Ortiz de Landaluce, E., Pérez-Lorente, F., Casas A., Jiménez-Vela, A. (2010): Virgen del Campo, La Senoba y Barranco de Valdecevillo. Tras la huella de los dinosaurios de Enciso. In: M. Moreno-Azanza, I. Díaz-Martínez, J.M. Gasca, M. Melero-Rubio, R. Rabal-Garcés, V. Sauqué, (eds.), VIII Encuentro de Jóvenes Investigadores en Paleontología, volumen de actas, Cidaris, 30: 339-347.

Dong, Z.M. (1990): Sauropoda from the Kelameili Region of the Junggar Basin, Xinjiang Autonomous Region. Vertebrata PalAsiatica, 28(1): 43-58.

Doublet, S. (2004): Contrôles tectonique et climatique de l'enregistrement stratigraphique dans un basin continental de rift: le bassin de Cameros. Unpublished PhD Thesis, University of Dijon, France: 494 p.

Forster, C.A. (1990): Evidence for juvenile groups in the ornithopod dinosaur Tenontosaurus tilletti Ostrom. Journal of Paleontology, 64(1): 164-165.

Galton, P.M., Farlow, J.O. (2003): Dinosaur State Park, Connecticut, USA: history, footprints, trackways, exhibits. Zubia, 21: 129-173.

García-Ortiz, E., Díaz-Martínez, I. (2008): Aportaciones de algunos yacimientos representativos de La Rioja al estudio del comportamiento de los dinosaurios. Palaeontologica Nova, SEPAZ, 2008, 8: 207-219.

García-Ortiz, E., Pérez-Lorente, F. (2012a): El comportamiento gregario. Revisión de los términos utilizados en paleontología de dinosaurios. In: C. Martínez-Pérez, M. Furió, A. Santos-Cubedo (eds.). Paleodiversity and Paleoecology of Iberian Ecosystems. Sot de Chera, Valencia: 78-80.

García-Ortiz, E., Pérez-Lorente, F. (2012b): Inferencias paleoecológicas sobre gregarismo en dinosaurios basadas en yacimientos de la Cuenca de Cameros (Cretácico Inferior), La Rioja, España. In: C. MartínezPérez, M. Furió, A. Santos-Cubedo (eds.). Paleodiversity and Paleoecology of Iberian Ecosystems. Sot de Chera, Valencia: 81-83.

Getty, P.R., Bush, A.M, Judge, A. (2011): Were Early Jurassic dinosaurs gregarious? New evidence from Dinosaur Footprint Reservation in Holyoke, Massachusetts. In: Geological Society of America Abstracts with Programs, 43(5): p. 310.

Haubold, H. (1971): Ichnia amphibiorum et reptiliorum fossilium. In: E. Kuhn (ed.), Handbuch der Paläoherpetologie, 18: 124 p.

Heinrich, W.D. (1999): The taphonomy of dinosaurs from the Upper Jurassic of Tendaguru (Tanzania) based on field sketches of the German Tendaguru Expedition (1909-1913). Mitteilungen aus dem Museum für Naturkunde Berlin, Geowissenschaftliche Reihe, 2: 25-61. 
Hernández Medrano, N., Pascual Arribas, C., Latorre Macarrón, P., Sanz Pérez, E. (2008): Contribución de los yacimientos de icnitas sorianos al registro general de Cameros. Zubía, 23-24: 79-120.

Hernández Medrano, N., Pérez-Lorente, F. (2003): Un nuevo yacimiento de icnitas de dinosaurio La Ilaga (Terroba, La Rioja, España). Suelo flexible y rastrilladas paralelas. In: F. Pérez-Lorente (Coord.). Dinosaurios y otros reptiles mesozoicos de España. Instituto de Estudios Riojanos. Logroño 26-29 Noviembre 2002, 26: 195-214.

Hernández Samaniego, A., Ramírez Merino, J.I., Olivé Davó, A., Álvaro López, M., Ramírez del Pozo, J., Aguilar, M.J., Meléndez Hevia, A. (1990): Hoja geológica num. 242, (Munilla). Mapa Geológico de España E. 1:50.000. Segunda serie-Primera edición. Instituto Tecnológico y GeoMinero de España., Madrid. Hoja y Memoria: 55 p.

Heymer, A. (1982): Diccionario Etológico. Ediciones Omega, Barcelona: 286 p. [translated from: Heymer, A. (1977): Ethological Dictionary: German-English-French. Garland, New York: 286 p.].

Hickman, C.P., Roberts, L.S., Larson, A. (2002): Principios integrales de zoología. Undécima edición. McGraw-Hill/Interamericana de España: 783-802. [translated from: Hickman, C.P., Roberts, Jr.L.S., Larson, A. (1996): Integrated principles of zoology. Dubuque, Iowa: Wm. C. Brown Publishers, Times Mirror Higher Education Group: 901 p.].

Horner, J.R. (1982): Evidence of colonial nesting and 'site fidelity' among ornithischian dinosaurs. Nature, 297: 675-676.

Horner, J.R. (1992): Dinosaur behavior and growth. In: R.S. Spencer (ed.). Fifth North American Paleontological Convention, Abstr. Progr., Paleontol. Soc. Spec. Publ., 6: 135 p.

Horner, J.R., Makela, R. (1979): Nest of juveniles provides evidence of family structure among dinosaurs. Nature, 282: 296-298.

Hooker, J.S. (1987): Late Cretaceous ashfall and the demise of a hadrosaurian "herd". In: Geological Society of America (Rocky Mountain Section) Abstracts with Programs, 19: 284 p.

Huene, F. (1928): Lebensbild des Saurischier-Vorkommens im obersten Keuper von Trossingen in Württemberg. Paleobiologica, 1: 103-116.

Immelmann, K., Beer, C. (1989): A dictionary of Ethology. Cambridge, Harvard University Press: 336 p.

Jain, S.L. (1980): The continental Lower Jurassic fauna from the Kota Formation, India. In: L.L. Jacobs (ed.), Aspects of Vertebrate History. Museum of Northern Arizona Review, Flagstaff: 99-123.

Kobayashi, Y., Lu, J.C. (2003): A new ornithomimid dinosaur with gregarious habits from the Late Cretaceous of China. Acta Palaeontologica Polonica, 48(2): 235-259.

Li, R., Lockley, M.G., Makovicky, P.J, Matsukawa, M., Norell, M.A., Harris, J.D., Liu, M. (2007): Behavioral and faunal implications of Early Cretaceous deinonychosaur trackways from China. Naturwissenschaften, 94: 657-665. doi: 10.1007/s00114-007-0310-7.

Lockley, M.G. (1986): The paleobiological and paleoenvironmental importance of dinosaur footprints. Palaios, 1: 37-47.

Lockley, M.G. (1989): Summary and prospectus. In: D.D. Gillette, M.G. Lockley (eds.), Dinosaur Tracks and Traces. Cambridge University Press, Cambridge: 441-447.

Lockley, M.G. (1991): Tracking Dinosaurs: A new Look at an Ancient World. Cambridge University Press, Cambridge: 238 p.

Lockley, M.G. (1995): Track records. Natural History, 104(6): p. 4651. Lockley, M.G., Huh, M., Kim, B.S. (2012a): Ornithopodichnus and PesOnly Sauropod Trackways from the Hwasun Tracksite, Cretaceous of Korea. Ichnos: An International Journal for Plant and Animal Traces, 19, 1-2: 93-100. doi: 10.1080/10420940.2011.625726.

Lockley, M.G., Huh, M., Gwak, S.G., Hwang, K.G., Paik, I.S. (2012b): Multiple Tracksites with Parallel Trackways from the Cretaceous of the Yeosu City Area Korea: Implications for Gregarious Behavior in Ornithopod and Sauropod Dinosaurs. Ichnos: An International Journal for Plant and Animal Traces, 19, 1-2: 105-114. doi: 10.1080/10420940.2011.625793.
Lockley, M.G., Hunt, A.P. (1995): Dinosaur Tracks and Other Fossil Footprints of the Western United States. Columbia University Press, New York: 338 p.

Lockley, M.G., Matsukawa, M. (1999): Some observations on trackway evidence for gregarious behavior among small bipedal dinosaurs. $\mathrm{Pa}$ laeogeography, Palaeoclimatology, Palaeoecology, 150: 25-31. doi: 10.1016/S0031-0182(99)00005-X.

Lockley, M.G., Meyer, C.A., dos Santos, V.F. (1994): Trackway evidence for a herd of juvenile sauropods from the Late Jurassic of Portugal. GAIA, 10: 27-35.

López Martínez, N., Lacasa Ruiz, A., Martínez-Desclós, X. (1997-98): Icnitas de dinosaurios saurópodos en el Cretácico Superior de Camarasa (Noguera, Lleida). Ilerda, 52: 35-46.

Lucas, S.G. (2007): Dinosaurios: Un libro de texto, Quinta edición. Ediciones Omega, Barcelona: xxiii +280 p. [translated from: Lucas, S.G. (2007): Dinosaurs: the Textbook, Fifth Edition. McGraw-Hill, New York: xxiii +280 p.].

Martín-Closas, C., Alonso, A. (1998): Estratigrafía y bioestratigrafía (Charophyta) del Cretácico Inferior en el sector occidental de la Cuenca de Cameros (Cordillera Ibérica). Revista de la Sociedad Geológica de España, 11: 253-269.

Mas, J.R., Alonso, A., Díaz, E. (1990): Tectonically controlled carbonate lacustrine systems in the northern margin of the Cameros Basin (Lower Cretaceous, north Spain). Comunication volume 6, Meeting of the European Geological Societies, Lisboa: p. 55.

Mas, R., Alonso, A., Guimerá, J. (1993): Evolución tectosedimentaria de una cuenca extensional intraplaca: La cuenca finijurásica-eocretácica de Los Cameros (La Rioja-Soria). Revista de la Sociedad Geológica de España, 6(3-4): 129-144.

Mas, J.R., Benito, M.I., Arribas, J., Alonso, A., Arribas, M.E., Lohomann, K.C., Hernán, J., Quijada, E., Suárez, P., Omodeo, S. (2011): Evolution of an intra-plate rift basin: the Latest Jurassic-Early Cretaceous Cameros Basin (Northwest Iberian Ranges, North Spain). GeoGuías, 8: 117-154.

Mas, R., Benito, M.I., Arribas, J., Serrano, A., Guimerà, J., Alonso, A., Alonso- Azcárate, J. (2002): La Cuenca de Cameros: desde la extensión finijurásica- eocretácica a la inversión terciaria-implicaciones en la exploración de hidrocarburos. Zubía Monográfico, 14: 9-64.

Matsukawa, M., Hamuro, T., Mizukami, T., Fujii., S. (1997): First trackway evidence of gregarious dinosaurs from the Lower Cretaceous Tetori Group of eastern Toyama prefecture, central Japan. Cretaceous Research, 18: 603-619. doi: 10.1006/cres.1997.0075.

Matsukawa, M., Lockley, M.G., Hunt, A.P. (1999): Three age groups of ornithopods inferred from footprints in the mid-Cretaceous Dakota Group, eastern Colorado, North America. Palaeogeography, Palaeoclimatology, Palaeoecology, 147: 39-51. doi: 10.1016/S00310182(98)00154-0.

Meléndez, A., Pérez-Lorente, F. (1996): Comportamiento gregario aparente de dinosaurios condicionado por una deformación sinsedimentaria (Igea, La Rioja, España). Estudios geológicos, 52(1-2): 77-82.

Meng, Q., Liu, J., Varricchio, D.J., Huang, T., Gao, C. (2004): Parental care in an ornithischian dinosaur. Nature, 431: 145-146. doi: $10.1038 / 431145 \mathrm{a}$.

Moratalla, J.J. (1993): Restos indirectos de dinosaurios del registro español: paleoicnología de la Cuenca de Cameros (Jurásico superiorCretácico inferior) y paleoología del Cretácico superior. Ph.D. Thesis Univ. Autónoma, Madrid: 729 p.

Moratalla, J.J., Hernán, J. (2010): Probable palaeogeographic influences of the Lower Cretaceous Iberian rifting phase in the Eastern Cameros Basin (Spain) on dinosaur trackway orientations. Palaeogeography, palaeoclimatology, palaeoecology, 295(1): 116-130. doi: 10.1016/j. palaeo.2010.05.027.

Moratalla, J.J., Sanz, J.L., Jiménez, S. (1988a): Multivariate analysis on Lower Cretaceous dinosaur footprints: discrimination between 
ornithopods and theropods. Geobios, 21(4): 395-408. doi: 10.1016/ S0016-6995(88)80042-1.

Moratalla, J.J., Sanz, J.L., Jiménez, S. (1988b): Nueva evidencia icnológica de dinosaurios en el Cretácico inferior de la Rioja (España). Estudios geológicos, 44: 119-131.

Moratalla, J.J., Sanz, J.L., Melero-Domínguez, I., Jiménez, S. (1988c): Yacimientos paleoicnológicos de La Rioja (Huellas de dinosaurios). Ed. Gobierno de La Rioja, Iberduero: 95 p.

Moratalla, J.J., Sanz, J.L., Jiménez, S. (1992): Hallazgos de nuevos tipos de huellas en La Rioja. Estrato, 4: 63-66.

Moratalla, J.J., Sanz, J.L., Jiménez, S. (1993): Nuevos hallazgos de icnitas de dinosaurios en Préjano e Inestrillas. La Rioja. Estrato, 5: 75-76.

Moratalla, J.J., Sanz, J.L., Jiménez, S. (1996): Nuevos yacimientos en Aldeanueva de Cameros y Trevijano. Estrato, 7: 111-113.

Moratalla, J.J., Sanz, J.L., Jiménez, S. (1997): Dinosaurios en La Rioja. Guía de yacimientos paleoicnológicos. Consejería de Educación, Cultura, Juventud y Deportes. Gobierno de La Rioja. Iberdrola, sección de Mineralogía y Paleontología: 175 p.

Moratalla, J.J., Sanz, J.L., Jiménez, S. (1999): Nuevos hallazgos de dinosaurios y pterosaurios en el Cretácico Inferior de La Rioja. Estrato, Revista riojana de arqueología, 10: 91-96.

Moreno, K., De Valais, S., Blanco, N.M., Tomlinson, A.J., Jacay, J., Calvo, J. (2012): Large theropod dinosaur footprint associations in western Gondwana: Behavioural and palaeogeographic implications. Acta Palaentologica Polonica, 57(1): 73-83. doi: 10.4202/app.2010.0119.

Moreno-Azanza, M., Gasca, J.M., Díaz-Martínez, I. Fernández, A., Canudo, J.I, Pérez-Lorente, F. (2013): Ootaxa assemblage from El Horcajo site (upper Berriasian, Cameros Basin) in Trevijano (La Rioja, Spain). Abstract book from the VI Jornadas internacionales sobre paleontología de dinosaurios y su entorno. 5-7 September, Salas de los Infantes: 93-95.

Myers, T.S., Fiorillo, A.R. (2009): Evidence for gregarious behaviour and age segregation in sauropods. Palaeogeography, Palaeoclimatology, Palaeoecology, 274: 96-104. doi: 10.1016/j.palaeo.2009.01.002.

Ösi, A., Pálfy, J., Makádi, L., Szentesi, Z., Gulyás, P., Rabi, M., Botfalvai, G., Hips, K. (2011): Hettangian (Early Jurassic) Dinosaur Tracksites from the Mecsek Mountains, Hungary. Ichnos, 18: 79-94. doi: 10.1080/10420940.2011.573603.

Ostrom, J.H., (1972): Were some dinosaurs gregarious? Palaeogeography, Palaeoclimatology, Palaeoecology, 11: 287-301. doi: 10.1016/0031-0182(72)90049-1.

Ostrom, J.H., (1985): Social and unsocial behavior in dinosaurs. Field Museum of Natural History Bulletin, 55(9): 10-21.

Pascual-Arribas, C., Hernández-Medrano, N. (2011): Posibles huellas de crias de terópodo en el yacimiento de Valdehijuelos (Soria, España). Studia geologica salmanticensia, 47: 77-110.

Pérez-Lorente, F. (1991): Excavaciones en Igea, Enciso y Munilla. Estrato, 3: 9-11.

Pérez-Lorente, F. (1992): Trabajos sobre icnitas en Igea, Enciso y Munilla. Estrato, 4: 59-62.

Pérez-Lorente, F. (1993): Excavaciones en Enciso, Igea y Munilla. Estrato, 5: 77-80.

Pérez-Lorente, F. (1999): Trabajos de restauración, mantenimiento y limpieza en los yacimientos de la Era del Peladillo 5, La Virgen del Campo y Las Losas. Estrato, Revista riojana de arqueología, 10: 8590.

Pérez-Lorente, F. (2001): Paleoicnología. Los dinosaurios y sus huellas en La Rioja. Apuntes para los cursos y campos de trabajo de verano. Gobierno de La Rioja (ed.): 227 p.

Pérez-Lorente, F. (2002): La distribución de yacimientos y de tipos de huellas de dinosaurio en la Cuenca de Cameros (La Rioja, Burgos, Soria, España). Zubia, 14: 191-210.

Pérez-Lorente, F. (2003a): Icnitas de dinosaurios del Cretácico en Es- paña. In: F. Pérez-Lorente (Coord.). Dinosaurios y otros reptiles mesozoicos de España. Instituto de Estudios Riojanos. Logroño 26-29 Noviembre 2002, 26: 49-108.

Pérez-Lorente, F. (2003b): Aportaciones de los yacimientos de la Barguilla, Santisol y Santa Juliana (Hornillos de Cameros, La Rioja. España). In: F. Pérez-Lorente (Coord.). Dinosaurios y otros reptiles mesozoicos de España. Instituto de Estudios Riojanos. Logroño 26-29 Noviembre 2002, 26: 161-194.

Pérez-Lorente, F., Cuenca-Besos, G., Aurell, M., Canudo, J.I., Soria, A.R., Ruiz-Omeñaca, J.I. (1997): Las Cerradicas tracksite (Berriasian, Galve, Spain): growing evidence for quadrupedal ornithopods. Ichnos, 5: 109-120. doi: 10.1080/10420949709386410.

Pérez-Lorente, F., Romero-Molina, M.M. (2001): Nuevas icnitas de dinosaurios terópodos y saurópodos en Galve y Miravete de la Sierra (Teruel, España). Geogaceta, 30: 115-118.

Pérez-Lorente, F., Romero-Molina, M.M., Pereda, J.C. (2000): Icnitas ornitópodas de El Contadero (Torremuña, La Rioja, España). Estructuras de barro y baja velocidad de marcha. Investigación Humanistica y Cientifica en la Rioja. Tomo homenaje a J. L. Fernández Sevilla y M. Balmaseda Aróspide, Instituto de Estudios Riojanos: 29-42.

Pérez-Lorente, F., Romero-Molina, M.M., Requeta, E., Blanco, M., Caro, S. (2001): Dinosaurios. Introducción y análisis de algunos yacimientos de sus huellas en La Rioja. Instituto de Estudios Riojanos (ed.), Logroño. Ciencias de la Tierra, 24: 102 p.

Piñuela, L., García-Ramos, J.C., Lires, J. (2002): Comportamiento gregario de ornitópodos en el Jurásico de Asturias. In: F. Pérez-Lorente (coord.). Congreso Internacional sobre dinosaurios y otros reptiles Mesozoicos de España. Resúmenes de las comunicaciones, ponencias y paneles, Logroño, 27 al 29 de noviembre de 2002: 44-45.

Pittman, J.G., Gillette, D.D. (1989): The Briar Site: a new sauropod dinosaur tracksite in Lower Cretaceous beds of Arkansas, USA. In: M.G. Lockley, D.D. Gillette (eds.), Dinosaur Tracks and Traces. Cambridge University Review, New York: 313-332.

Porfiri, J.D., Calvo, J.O., Santos, D.D. (2007): Evidencia de gregarismo en Megaraptor namunhuaiquii (Theropoda, Tetanurae), Patagonia, Argentina. In: Díaz-Martínez, E., Rábano, I. (eds.) European Meeting on the paleontolgy and stratigraphy of Latin America 4, Madrid. Cuadernos del Museo Geominero, 8. Instituto Geológico y Minero de España, Madrid:

Quijada, I.E., Suarez-Gonzalez, P., Benito, M.I., Mas R. (2013): New insights on stratigraphy and sedimentology of the Oncala Group (eastern Cameros Basin): implications for the paleogeographic reconstruction of NE Iberia at Berriasian times. Journal of Iberian Geology, 39(2): 313-334. doi: 10.5209/rev JIGE.2013.v39.n2.42503.

Riveline, J., Berger, J.P., Feist, M., Martín-Closas, C., Schudack, M., Soulie-Maersche, I. (1996): European Mesozoic-Cenozoic charophyte biozonation. Bulletin de la Société géologique de France, 167(3): 453-468.

Roach, B.T., Brinkman, D.L. (2007): A Reevaluation of Cooperative Pack Hunting and Gregariousness in Deinonychus antirrhopus and Other Nonavian Theropod Dinosaurs. Peabody Museum of Natural History Bulletin, 48(1): 103-138. doi:10.3374/0079-032X(2007)48[1 03:AROCPH]2.0.CO;2.

Rogers, R.R. (1990): Taphonomy of three dinosaur bonebeds in the Upper Cretaceous Two Medicine Formation of northwestern Montana; evidence for drought-related mortality. PALAIOS, 5(5): 394-413.

Romero-Molina, M.M., Sarjeant, W.A.S., Pérez-Lorente, F., López, A., Requeta, E. (2003): Orientation and characteristics of theropod trackways from the Las Losas Palaeoichnological site (La Rioja, Spain). Ichnos, 10: 241-254. doi: 10.1080/10420940390255529.

Romilio, A., Salisbury, S.W. (2010): A reassessment of large theropod dinosaur tracks from the mid-Cretaceous (late Albian-Cenomanian) Winton Formation of Lark Quarry, central-western Queensland, Aus- 
tralia: A case for mistaken identity. Cretaceous Research, 32: 135142. doi: 10.1016/j.cretres.2010.11.003.

Sander, P.M., Mateus, O., Laven, T., Knötschke, N. (2006): Bone histology indicates insular dwarfism in a new Late Jurassic sauropod dinosaur. Nature, 441: 739-741. doi: 10.1038/nature04633.

Sarjeant, W.A.S., Romero-Molina, M.M., López, A., Pérez-Lorente, F., Requeta, E. (2002): Algunas implicaciones de la orientación y características de las huellas terópodas digitígradas, semiplantígradas, irregulares y con marcas de Uña del yacimiento de Las Losas (La Rioja, España). In: F. Pérez-Lorente (Coord.). Congreso Internacional sobre Dinosaurios y otros Reptiles Mesozoicos de España, Logroño 27-29 de noviembre de 2002. Resúmenes de las comunicaciones y ponencias: p. 63.

Sarmiento, F.O. (2001): Diccionario de Ecología de Paisajes, Conservación y Desarrollo Sustentable para Latinoamérica. Editorial AbyaYala, Quito: 226 p.

Schulp, A.S., Brokx, W.A. (1999): Maastrichtian Sauropod Footprints from the Fumanya Site, Berguedŕ, Spain. Ichnos, 6: 239-250. doi: 10.1080/10420949909386455.

Schwartz, H.L., Gillette, D.D. (1994): Geology and taphonomy of the Coelophysis quarry, Upper Triassic Chinle Formation, Ghost Ranch, New Mexico. Journal of Paleontology, 68: 1118-1130.

Soler, M., Carranza, J., Cordero Rivera, A., Moreno, J., Senar, J.C., Soler, J.J. (2001): Traducción al español de los términos ingleses más conflictivos utilizados en Etología, Ecología y Evolución. Etología, 9: 43-46.

Suarez-Gonzalez, P., Quijada, I.E., Benito, M.I., Mas, R. (2013): Eustatic versus tectonic control in an intraplate rift basin (Leza Fm, Cameros Basin). Chronostratigraphic and paleogeographic implications for the Aptian of Iberia. Journal of Iberian Geology, 39(2): 285-312. doi: 10.5209/rev JIGE.2013.v39.n2.42502.

Suárez-González, P., Quijada, I.E., Mas, J.R., Benito, M.I. (2010): Nuevas aportaciones sobre la influencia marina y la edad de los carbonatos de la Fm Leza en el sector de Préjano (SE de La Rioja). Cretácico Inferior, Cuenca de Cameros. Geogaceta, 49: 7-10.

Thulborn, R.A. (1990): Dinosaur tracks. Chapman and Hall: 410 p.

Thulborn, R.A. (2011): Lark Quarry revisited: a critique of methods used to identify a large dinosaurian track-maker in the Winton For- mation (Albian-Cenomanian), western Queensland, Australia. Cretaceous Research, 2011. doi: 10.1016/j.cretres.2011.11.006.

Thulborn, R.A., Wade, M. (1979): Dinosaur stampede in the Cretaceous of Queensland. Lethaia, 12: 275-279. doi: 10.1111/j.1502-3931.1979. tb01008.x

Thulborn, R.A., Wade, M. (1984): Dinosaur trackways in the Winton Formation (mid-Cretaceous) of Queensland. Memoirs of the Queensland Museum, 21: 413-517.

Tischer, G. (1966): Über die Wealden-Ablagerung und die Tektonik der östlichen Sierra de los Cameros in der nordwestlichen Iberischen Ketten (Spanien). Geologisches Jahrbuch Beihefte, 44: 123-164.

Varricchio, D.J., Sereno, P.C., Zhao, X., Tan, L., Wilson, J.A., Lyon, G.H. (2008): Mud-trapped herd captures evidence of distinctive dinosaur sociality. Acta Palaeontologica Polonica, 53(4): 567-578. doi: 10.4202/app.2008.0402.

Viera, L.I., Torres, J.A. (1979): El Wealdico de la Zona de Enciso (sierra de los Cameros) y su fauna de grandes reptiles. Munibe, 31: 141-157.

Viera, L.I., Torres, J.A. (1992): Sobre "Dinosaurios coelúridos gregarios en el yacimiento de Valdevajes (La Rioja, España)". Nota de réplica y crítica. Revista Española de Paleontología, 7(1): 93-96.

Viera, L.I., Torres, J.A., Aguirrezabala, L.M. (1984): El Weald de Munilla (La Rioja) y sus icnitas de dinosaurios (II). Munibe, 36: 3-22.

Vila, B., Oms, O., Marmi, J., Galobart, A., Gaete, R. (2006): Los últimos dinosaurios de los Pirineos y sus huellas. Enseñanza de las Ciencias de la Tierra, 14.3: 240-246.

Winkler, D.A., Gomani, E.M., Jacobs, L.L. (2000): Comparative taphonomy of an Early Cretaceous Sauropod Quarry, Malawi, Africa. Paleontological Society of Korea Special Publication, 4: 99-114.

Winkler, D.A., Murray, P.A. (1989): Paleoecology and hypsilophodontid behavior at the Proctor Lake dinosaur locality (Early Cretaceous), Texas. Geological Society of America Special Paper, 238: 55-61.

Xia, W., Li, X., Yi, Z. (1984): The burial environment of dinosaur fauna in Lower Shaximiao Formation of Middle Jurassic at Dashanpu, Zigong, Sichuan. Journal of Chengdu Institute of Technology, 2: 46-59.

Yadagiri, P. (2001): The osteology of Kotasaurus yamanpalliensis, a sauropod dinosaur from the Early Jurassic Kota Formation of India. Journal of Vertebrate Paleontology, 21: 242-252. doi: 10.1671/0272-4634(2001)021[0242:TOOKYA]2.0.CO;2. 